OPEN ACCESS

Edited by:

David Emerson,

Bigelow Laboratory for Ocean

Sciences, USA

Reviewed by:

Olivier Rouxel,

Institut Français de Recherche pour

l'Exploitation de la Mer, France

Danielle Fortin

University of Ottawa, Canada

*Correspondence:

Miguel Iniesto,

Microbial Ecology Laboratory,

Department of Ecology, Facultad de Ciencias, Universidad Autónoma de Madrid, c/Darwin 2, 28049 Madrid,

Spain

miguel.iniesto@uam.es

Specialty section

This article was submitted to

Microbiological Chemistry and

Geomicrobiology,

a section of the journal

Frontiers in Earth Science

Received: 06 May 2015

Accepted: 18 August 2015

Published: 04 September 2015

Citation:

Iniesto M, Zeyen N, López-Archilla Al,

Bernard S, Buscalioni ÁD, Guerrero

MC and Benzerara K (2015)

Preservation in microbial mats:

mineralization by a talc-like phase of a

fish embedded in a microbial

sarcophagus. Front. Earth Sci. 3:51.

doi: 10.3389/feart.2015.00051

\section{Preservation in microbial mats: mineralization by a talc-like phase of a fish embedded in a microbial sarcophagus}

\author{
Miguel Iniesto ${ }^{1 *}$, Nina Zeyen ${ }^{2}$, Ana I. López-Archilla ${ }^{1}$, Sylvain Bernard ${ }^{2}$, \\ Ángela D. Buscalioni ${ }^{3}$, M. Carmen Guerrero ${ }^{1}$ and Karim Benzerara ${ }^{2}$ \\ ${ }^{1}$ Microbial Ecology Laboratory, Department of Ecology, Universidad Autónoma de Madrid, Madrid, Spain, ${ }^{2}$ Institut de \\ Minéralogie, de Physique des Matériaux, et de Cosmochimie, Sorbonne Universités, Centre National de la Recherche \\ Scientifique, Unité Mixte de Recherche 7590, Université Pierre et Marie Curie, Muséum National d'Histoire Naturelle, Institut \\ de Recherche Pour le Développement Unité Mixte de Recherche 206, Paris, France, ${ }^{3}$ Paleontology Laboratory, Department \\ of Biology, Universidad Autónoma de Madrid, Madrid, Spain
}

Microbial mats have been repeatedly suggested to promote early fossilization of macroorganisms. Yet, experimental simulations of this process remain scarce. Here, we report results of 5 year-long experiments performed onfish carcasses to document the influence of microbial mats on mineral precipitation during early fossilization. Carcasses were initially placed on top of microbial mats. After 2 weeks, fish became coated by the mats forming a compact sarcophagus, which modified the microenvironment close to the corpses. Our results showed that these conditions favored the precipitation of a poorly crystalline silicate phase rich in magnesium. This talc-like mineral phase has been detected in three different locations within the carcasses placed in microbial mats for more than 4 years: (1) within inner tissues, colonized by several bacillary cells; (2) at the surface of bones of the upper face of the corpse buried in the mat; and (3) at the surface of several bones such as the dorsal fin which appeared to be gradually replaced by the Mg-silicate phase. This mineral phase has been previously shown to promote bacteria fossilization. Here we provide first experimental evidence that such Mg-rich phase can also be involved in exceptional preservation of animals.

Keywords: Mg-silicate biomineralization, fish preservation, fossilization, microbial mat, experimental taphonomy

\section{Introduction}

The role of microbial mats in fossilization has been inferred based on several lines of evidence. First, microbial communities can remodel sediments, generating rare but clearly distinguishable features that have been named microbially-induced sedimentary structures (MISS, Gerdes et al., 1993; Hagadorn and Bottjer, 1997; Noffke et al., 2001; Noffke, 2009). MISS have favored preservation of body impressions or the formation of death masks, such as those found in the Ediacaran period (Gehling, 1999; Narbonne, 2005; Laflamme et al., 2011), or footprints of Late Jurassic sauropods (Marty et al., 2010). In addition, the frequent association of bacterial cells with exceptionally preserved fossils supports the link between fossilization and microbial mats. For example, the coverage of fossils of macroorganisms by fossil microbial cells has been detected in sites of different ages, belonging to diverse 
Konservat-Lagerstätten such as, for instance, Las Hoyas (Cretaceous, Spain) (Briggs et al., 1997; Gupta et al., 2008) or Nuspligen (Jurassic, Germany) (Briggs et al., 2005). This preserved association of microbial cells with fossils has also been observed in some pseudomorphs, replicating original tissues: for example, this is the case of the eye of a teleostean fish from Las Hoyas (Gupta et al., 2008) or several dinosaurian fossil bones of different ages (Kaye et al., 2008).

The precise mechanisms explaining how microbial mats favor the preservation of fossilized macroorganisms are yet to be clarified. One reason might be related to their capability to induce mineral precipitation, leading to the formation of lithified layers (Visscher et al., 1998; Dupraz and Visscher, 2005; Vasconcelos et al., 2006; Dupraz et al., 2009), which may protect dead bodies from advanced degradation. Li et al. (2013) stressed on the pivotal role of microbially-induced authigenic mineralization in fossilization and it has been reported in many instances that bacterial cells are themselves preserved when mineral formation occurs within and/or at cell surfaces (Couradeau et al., 2013; Gérard et al., 2013).

Despite previous geobiological observations, there are still few experimental studies simulating fossilization of macroorganisms by microbial mats. Recently, taphonomic experiences have successfully shown the possibility of increased fossil preservation using microbial mats (Iniesto et al., 2013b; Guerrero et al., in press). For example, the role played by microbial mats in the cementation and the consequent preservation of footprints has been tested by Marty et al. (2009). The ability of mats to stabilize sediments by their cementation around carcasses and induction of authigenic mineralization has been achieved experimentally by Darroch et al. (2012). The preservation of an accurate impression and the formation of a mold have also been tested (Iniesto et al., 2013a) as well as the generation and maintenance of a microenvironment close to preserved corpses (Iniesto et al., 2010). In addition, Iniesto et al. (2013b) described a Ca-rich veil covering the upper surface of carcasses after 15 days. However, the extent of mineralization of carcasses, the identity of the involved minerals as well as their spatial distribution within the microbial sarcophagus remain poorly assessed. Since chemical conditions change significantly at the microenvironment-scale during the early fossilization (Iniesto et al., 2015), the precipitation of diverse mineral phases may occur. However, the importance of this process in the preservation of soft tissue of carcasses inside the microbial sarcophagus requires further evidence.

Here, we report and discuss the results of a 5-year long experiment consisting in the coverage of fish carcasses by microbial mats in order to explain and better understand the mineralization process into the sarcophagus generated by microbial mats. To identify and describe the expected precipitates, we used a combination of bulk scale and micro- and nano-scale analyses, including x-ray diffraction (XRD), Raman microspectroscopy, scanning electron microscopy (SEM) (see Beyssac et al., 2003 or Bernard et al., 2008 for more frequent RAMAN applications). Focused ion beam (FIB) milling and transmission electron microscopy (TEM) allow the accurate characterization of mineral phases in these biological systems and the observation of the relations between tissues and microbial cells as shown by previous studies (e.g., Benzerara et al., 2005a,b).

\section{Materials and Methods}

\section{Microbial Mats and Fish Carcasses}

Microbial mat samples used for the taphonomy experiment were collected from the shallow lake Salada de Chiprana (Zaragoza, Spain). The lake is fed by groundwater discharge, which provides a source of abundant magnesium sulfate (up to 700 meq. $\mathrm{L}^{-1}$ of $\mathrm{SO}_{4}^{2-}$ and $\mathrm{Mg}^{2+}$ ) and sodium chloride (approximately 300 meq. $\left.\mathrm{L}^{-1}\right)$. A more detailed water composition is provided by Guerrero et al. (1991). The salinity of the lake water is high, varying between 30 and $70 \%$ due to the changes in the volume of surface run-off which supplies the lake with abundant nutrients (Berga et al., 1994). Together with high $\mathrm{pH}$ (values above 9), this results in an extensive coverage by microbial mats of the shore down to a depth of $1.5 \mathrm{~m}$ (Guerrero et al., 1991). The "Salada de Chiprana" mats are dominated by the filamentous cyanobacterium Coleofasciculus chthonoplastes (Thuret ex Gomont) Siegesmund et al. (2008) (formerly known as Microcoleus chthonoplastes Thuret ex Gomont), determining the coherence of the community. The taxa of the upper mat layer are mainly Chloroflexus, Coleofasciculus, and Pseudoanabaena-like and the underlying darker layer is made up of dead cyanobacteria, frustules of diatom and anoxic microbial populations (Jonkers et al., 2003). The "Salada de Chiprana" mats lie on detritic material, deposited by an ancient network of Tertiary paleochannels composed of fossilized sands which now remain as ridges due to the differential erosion of the less resistant silt deposits between channels (Friend et al., 1986).

Microbial mats were ground until homogenization and inoculated in glass tanks $(50 \times 20 \times 18 \mathrm{~cm})$ over a layer of sediments collected from the same lake. The resulting community was similar to the natural one, with millimetric multi-layered structure, due to differential growth along a vertical gradient of physicochemical characteristics (Cohen, 1989; Wierzchos et al., 1996). Layers were active during the course of the experiment, with oxygenic photosynthetic (mainly filamentous cyanobacteria and several diatoms) and aerobic heterotrophic microorganisms in the oxic upper layer, laid over several anoxygenic photosynthetic bacteria (Chromatiaceae and Chlorobiaceae groups), and anaerobic microorganisms (e.g., fermenters or sulfate-reducing bacteria) in the anoxic deep layer (Jonkers et al., 2003). One similar glass tank without microbial mat was used as a control. To prevent the formation of a microbial mat, we maintained this tank in the dark. In this way, cyanobacteria could not multiply and therefore they could not form the framework necessary for the build-up of mats. A large diversity of non-phototrophic bacteria likely colonized this tank but we could clearly observed that no mat was formed. The tanks were filled with water from Chiprana to obtain a $1 \mathrm{~cm}$ deep water column. The water losses resulting from evaporation were periodically compensated by adding sterilized distilled water. The system was illuminated (OSRAM DECOSTAR 51 TITAN) with a photoperiod of $10 \mathrm{~h}$ of daylight. 
The small fish Paracheirodon innessi (neon tetra) was used as a model for macroorganisms. Six fish were laid at the surface of the microbial mat with a gap between the fish (Figure 1A). Three fish were analyzed after 4 years of experiments. Three others were analyzed after 5 years. Six additional fish were placed on control sediments in analogous tanks and kept in the dark to prevent the growth of an actual microbial mat as explained above (Figure 1B). Fish were killed immediately before the experiment following the standard animal care protocol used at the Universidad Autónoma de Madrid. Fish used as controls decayed so much that they were barely recognizable after 4 years and could not be collected (Iniesto et al., 2013b). Structures such as bones and fins, initially hard, broke up during the handling of the sample, showing their high decay. In contrast, fish deposited at the surface of the mats were quickly covered by the microbial communities. The sarcophagus formed by the mats protected carcasses and made their decomposition much slower compared to controls (Guerrero et al., in press).

\section{Scanning Electron Microscopy (SEM) and Energy Dispersive X-ray Spectrometry (EDXS)}

For electron microscopy analyses, samples of fish embedded within microbial sarcophagi and the underlying sediments were fixed in glutaraldehyde (2\%) overnight and dehydrated in a gradual series of ethanol baths (50, 70, and 100\%). Once dried, samples were embedded in epoxy resin, sectioned with a diamond saw blade along a coronal plane (Figure 1C) and polished with diamonds down to $3 / 4 \mu \mathrm{m}$ in size. Samples were then coated with carbon. Images and analyses were collected in backscattered and secondary electron modes using a Zeiss Ultra 55 FEG-SEM operating at $15 \mathrm{kV}$, with a $60 \mu \mathrm{m}$ aperture at a working distance of $\sim 7.5 \mathrm{~mm}$. Elemental compositions were determined using energy dispersive $\mathrm{x}$ ray spectrometry (EDXS) with a Bruker QUANTAX system. EDXS maps were processed using the software Esprit 1.9 (BRUKER).

\section{Focused Ion Beam (FIB) Milling and Scanning Transmission Electron Microscopy (STEM)}

Several areas observed by SEM were selected to excavate electron-transparent foils by focused ion beam (FIB) milling. These foils were then be analyzed down to the nm-scale by scanning transmission electron microscopy (STEM) similarly to numerous previous studies on mineral-living organism assemblages (e.g., Benzerara et al., 2005a,b; Bernard et al., 2010). FIB milling was performed using a FEI strata DualBeam 235.

STEM observations of the ultrathin foils were carried out using a JEOL2100F (JEOL Ltd, Japan) microscope operating at $200 \mathrm{kV}$, equipped with a field emission gun and a high resolution UHR pole piece. STEM imaging allows Z-contrast imaging in the high angle annular dark field (HAADF) mode. Elemental mapping was acquired by EDXS in the STEM mode with a $1 \mathrm{~nm}$ probe. Selected area electron diffraction (SAED) was performed using the smallest aperture allowing retrieval of diffraction patterns from a $100 \times 100 \mathrm{~nm}$ area.
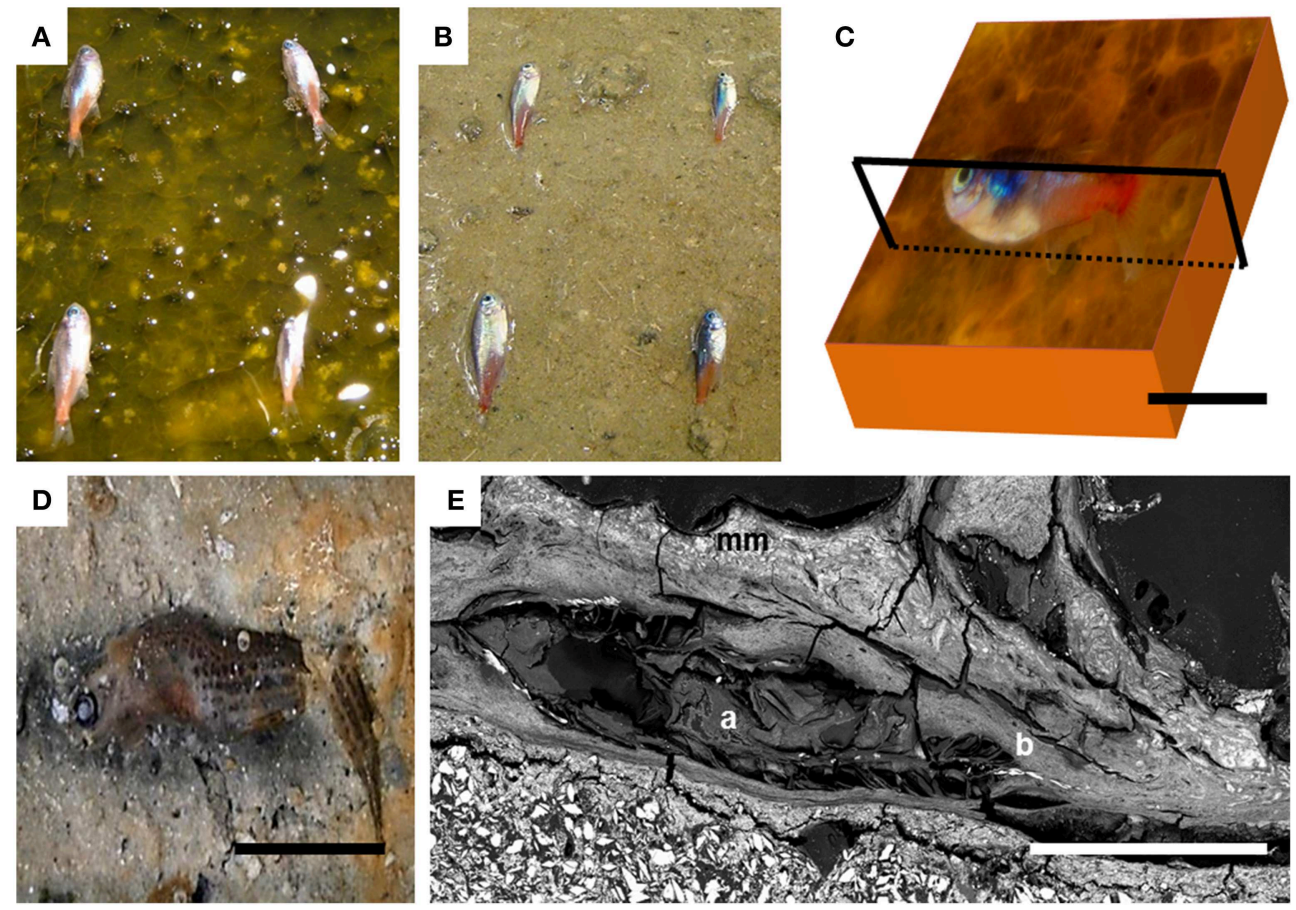

FIGURE 1 | Experimental setup showing how fish were placed (A) on the mat and (B) directly on the sediments in the control tank at the beginning of the experiment. (C) Sketch showing the plane of the section for the SEM preparation. (D) Image of the advanced decay of control fish after day 90 over the sediment. (E) SEM image of the fish trapped by the microbial mat after 4 years; (mm) microbial mat; (a) swim bladder; (b) vertebral column. Scale bar represents $1 \mathrm{~cm}$ in (C-E). 


\section{X-ray Diffraction (XRD) and Raman Microspectroscopy}

The sediment was kept overnight at $37^{\circ} \mathrm{C}$ and dry-crushed until obtaining a homogeneous powder. XRD measurements were performed using the $\mathrm{Co} \mathrm{K} \alpha$ radiation (1.7889 $\AA$ ) on a Panalytical X'Pert Pro MPD diffractometer mounted in Bragg-Brentano configuration. Data were recorded over a $4-70^{\circ}$ $2 \theta$ range with a step of $0.017^{\circ}$ and a counting time of $3.5 \mathrm{~h}$ per sample. Raman microspectroscopy was performed using a Renishaw InVIA Reflex microspectrometer. Rationale for Raman analyses can be found in Bernard et al. (2008) and Beyssac and Lazzeri (2012). We used a $514 \mathrm{~nm}$ Laser Physics argon laser in circular polarization. The spectrometer was first calibrated with a silicon standasrd. The laser was focused on the sample through a DMLM Leica microscope with a $100 \mathrm{X}$ objective (NA = 0.85), and the laser power at the sample surface was set around $1 \mathrm{~mW}$. The Rayleigh diffusion was eliminated by edge filters, and the entrance slit was closed down to $15 \mu \mathrm{m}$ to achieve nearly confocal configuration. The signal was finally dispersed using 1800 lines $/ \mathrm{mm}$ grating and analyzed by a Peltier-cooled RENCAM CCD detector.

\section{Water Analysis}

Conductivity, temperature and $\mathrm{pH}$ of the water column were measured once a week with the corresponding electrodes (WTWLF 330 conductivity meter and a 323 A WTW pH meter, respectively). Solutions percolating the microbial mat and the controls were analyzed in order to determine the composition of the porewater. Water was collected from the bottom of the tanks, in direct contact with sediments, and filtered at $0.2 \mu \mathrm{m}$. Concentrations of $\mathrm{F}^{-}, \mathrm{Cl}^{-}$, and $\mathrm{SO}_{4}^{2-}$ were determined by ion chromatographic analyses. For these analyses, water samples were diluted 90 times with milli-Q water. Concentrations of $\mathrm{Ca}$, $\mathrm{Mg}, \mathrm{Si}, \mathrm{Na}, \mathrm{K}$ and $\mathrm{B}$, and $\mathrm{Sr}$ were measured by inductively coupled plasma atomic emission spectroscopy (ICP-AES). For ICP-AES analyses, filtered samples were acid stabilized (with $\mathrm{HCl} 2 \%$ ) soon after collection. For these analyses, water samples were diluted with nitric acid at 2\% 50 times for B and Sr, 150 times for $\mathrm{K}$ and $\mathrm{Na}$ and 3200 times for $\mathrm{Ca}$ and $\mathrm{Mg}$. Finally, the concentration in $\mathrm{Si}$ (measured as $\mathrm{H}_{4} \mathrm{SiO}_{4}$ ) was also checked by continuous flow colorimetric analyses. For these analyses, water samples were diluted 10 times with milli-Q water. Commercial mineral water (Volvic) was used as a control. Ionic activities and saturation index were calculated using the Visual Minteq software.

\section{Results}

\section{Mineralogical Analyses of the Sediments}

SEM and XRD analyses were combined to identify the major mineral phases forming the sediments beneath the microbial mats (Figures 2A-D, 3, respectively). The detected mineral assemblage was characteristic of an evaporitic environment as this is the case in lake Salada de Chiprana. Gypsum $\left(\mathrm{CaSO}_{4} \cdot 2 \mathrm{H}_{2} \mathrm{O}\right)$ with XRD peaks at $13.5^{\circ}, 24.1^{\circ}$, and $33.9^{\circ}(2 \theta)$ was the most abundant phase. Quartz $\left(\mathrm{SiO}_{2}\right)$ with XRD peaks at 31 and $24.3^{\circ}(2 \theta)$ and kieserite, an evaporitic hydrated magnesium sulfate $\left(\mathrm{MgSO}_{4} \cdot \mathrm{H}_{2} \mathrm{O}\right)$ with peaks at $30.4^{\circ}, 31.1^{\circ}$, and $21.4^{\circ}(2 \theta)$ were also detected. The presence of gypsum was confirmed by Raman analyses (Figure 4A) with peaks at 415,494 , and $670 \mathrm{~cm}^{-1}$ attributed to the bending of the $\mathrm{SO}_{4}$ tetrahedra ( $v 2$ symmetric, $v 2$ symmetric, and $v 4$ antisymmetric, respectively) and peaks at 1008 and $1136 \mathrm{~cm}^{-1}$
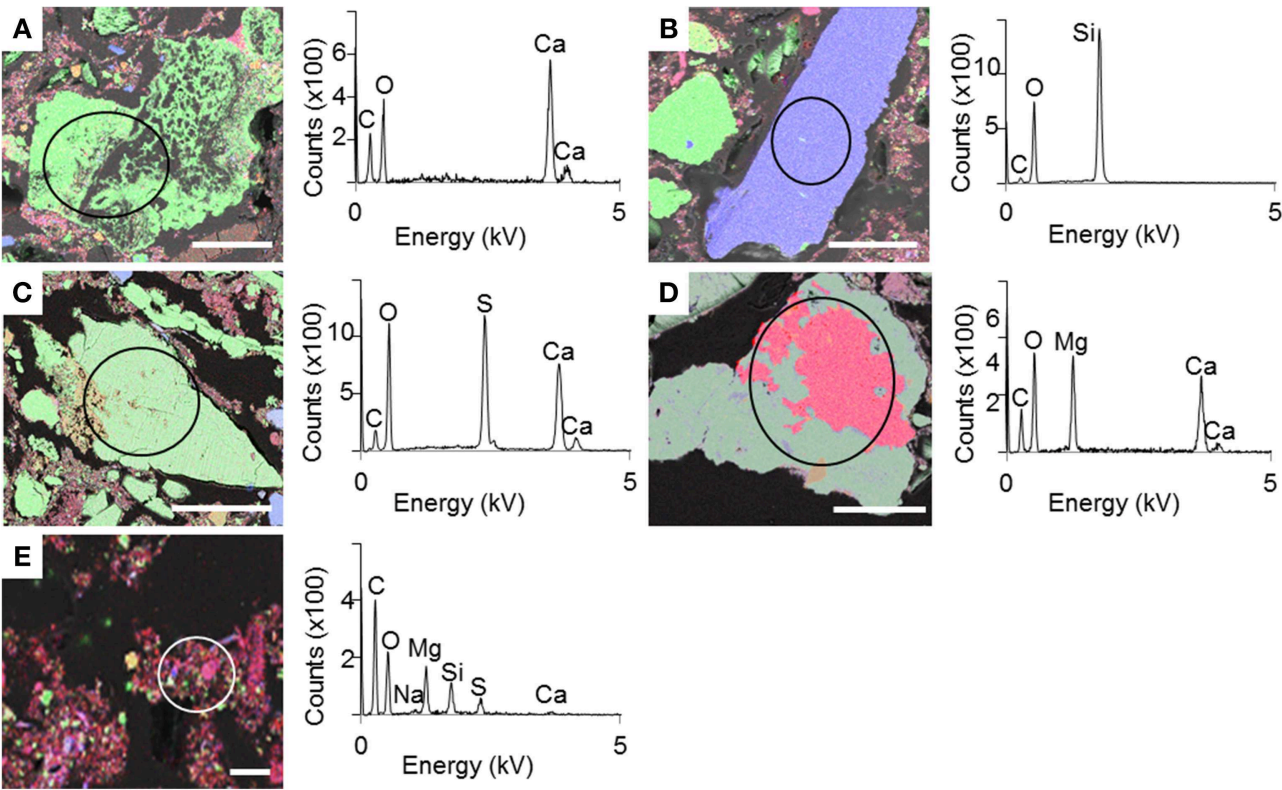

FIGURE 2 | SEM-EDXS maps of the sediment beneath the microbial mat with the corresponding EDXS spectra. (A-E) Different mineral phases observed in the sediment. Color legend: green-Ca; blue-Si; red-Mg. Scale bar represents $100 \mu \mathrm{m}$ for (A-D) and $10 \mu \mathrm{m}$ for (E) 


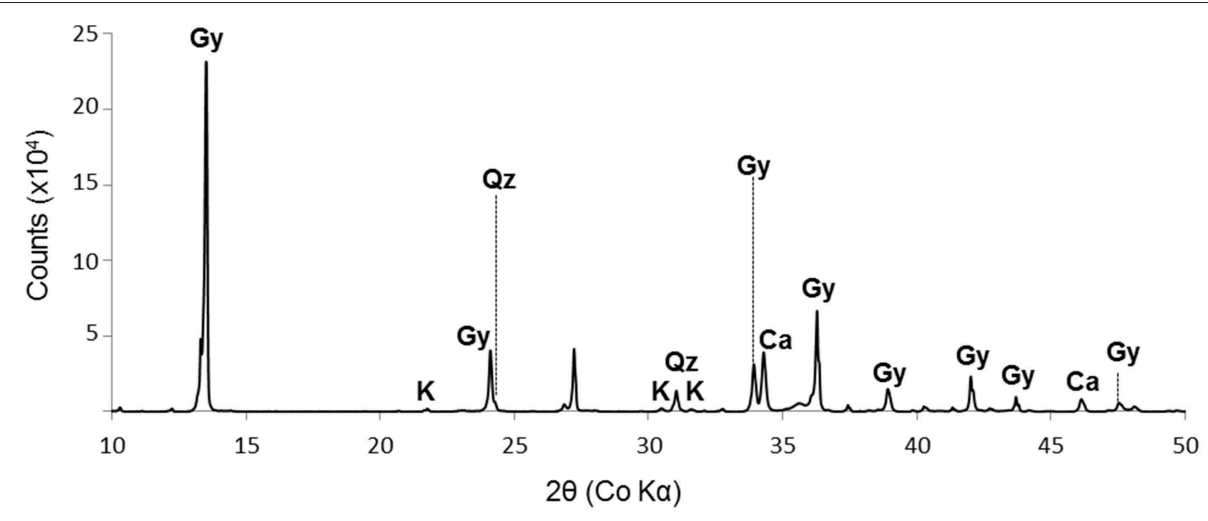

FIGURE 3 | XRD spectrum of the sediment beneath the microbial mat. Gy, gypsum $\left(\mathrm{CaSO}_{4} \cdot 2 \mathrm{H}_{2} \mathrm{O}\right) ; \mathrm{K}$, kieserite $\left(\mathrm{MgSO}_{4} \cdot \mathrm{H}_{2} \mathrm{O}\right) ; \mathrm{Qz}, \mathrm{quartz}(\mathrm{SiO})$; $\mathrm{Ca}$, calcite $\left((\mathrm{Ca}, \mathbf{M g}) \mathrm{CO}_{3}\right)$ with undetermined $\mathrm{Ca} / \mathrm{Mg}$ ratio. The diagram shows data from $10^{\circ}$ to $50^{\circ}(2 \theta)$.

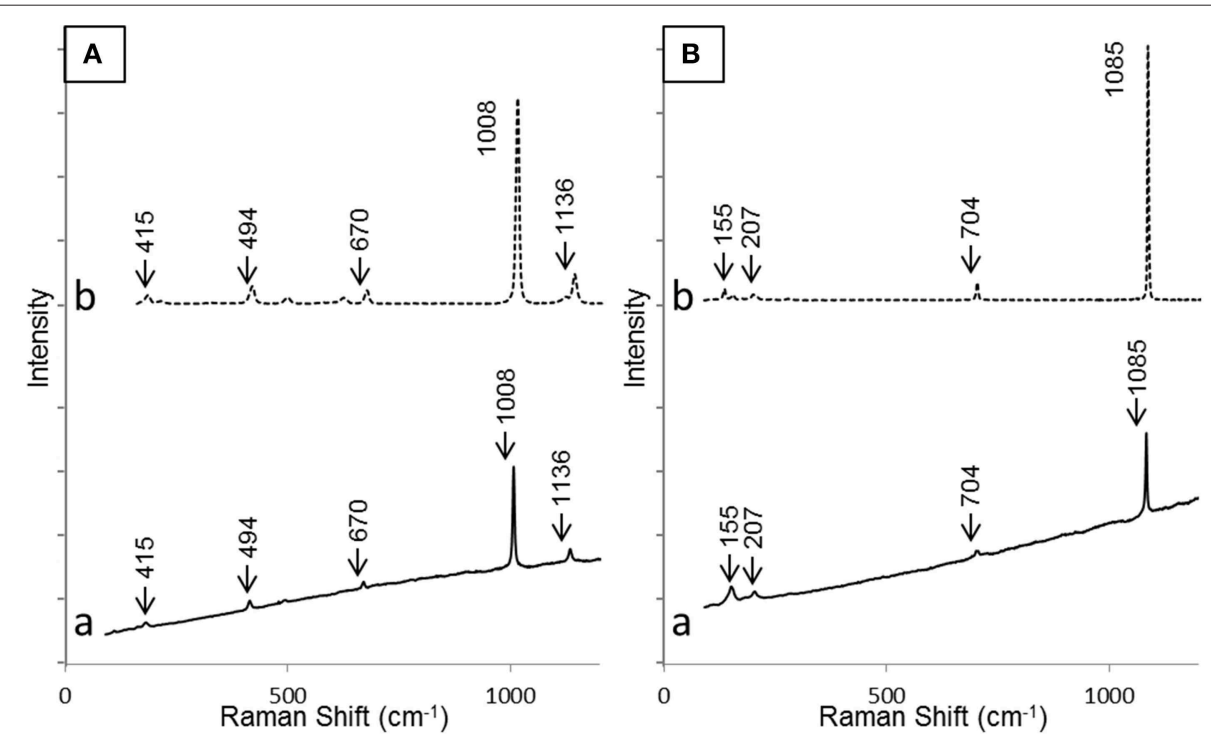

FIGURE 4 | Raman spectra of gypsum (A) and aragonite (B) as detected in the sediment beneath the microbial mat (a) and corresponding reference spectra from RRUFF database (b). Bands relevant for identification have been highlighted in both cases.

resulting from the $\mathrm{SO}_{4}$ stretching vibrations $v 1$ and $v 3$ (Liu et al., 2009; White, 2009). Aragonite was also evidenced by Raman spectroscopy (Figure 4B) with diagnostic peaks at 155 and $207 \mathrm{~cm}^{-1}$ that correspond to the transitional and librational lattice modes, and 704 and $1085 \mathrm{~cm}^{-1}$ attributed, respectively, to the bending ( $v 4$ vibration) and symmetric stretching ( $v 1$ vibration) of the carbonate group (Urmos et al., 1991; White, 2009). An additional carbonate mineral phase, likely corresponding to a $(\mathrm{Ca}, \mathrm{Mg})$-calcite, was detected in diffractograms (peaks $34.28^{\circ}$ and $46^{\circ}$, Figure 3) but not by Raman spectroscopy. Raman spectro-microscopy and XRD analyses were consistent with analyses performed by SEM-EDXS. Additional phases not evidenced by XRD could be detected in the sediments by SEM suggesting that they are minor and/or poorly crystalline. This includes an abundant $\mathrm{Mg}$ - and Si-rich phase (Figure 2E).

\section{Water Composition}

Physico-chemical parameters at the beginning of the experiment were: a temperature of $20.8 \pm 1.3^{\circ} \mathrm{C}$, a pH of $8.4 \pm 0.4$ and a conductivity of $52.9 \pm 0.6 \mathrm{mS} \cdot \mathrm{cm}^{-1}$ for the microbial mat tank. The control tank, i.e., the one without microbial mat, had a temperature of $20.7 \pm 1.4^{\circ} \mathrm{C}$, a $\mathrm{pH}$ of $8.3 \pm 0.5$ and a conductivity of $50.1 \pm 1.8 \mathrm{mS} \cdot \mathrm{cm}^{-1}$ (Table 1). Solutions percolating the control and the microbial mat tanks contained large amounts of $\mathrm{Cl}^{-}$(between $\sim 660$ and $830 \mathrm{mM}$ ) and $\mathrm{SO}_{4}^{2-}$ (between $\sim 847$ and $1031 \mathrm{mM}$ ) consistently with the evaporitic origin of the sediments (Table 1). Concentrations were different between the control and the microbial mat tanks but this could be due to some variations in the mineralogical composition in the different tanks. In addition, the opaque lid covering the control tank likely affects evaporation as suggested by the comparison with the initial values of the water column conductivity (Table 1). 
TABLE 1 | Concentrations (in $\mathrm{mM}$ ) of cations and anions in the water percolating the sediments, from the initial water pool, the tank with microbial mat and the control (without mat) tank, determined by ICP-AES, colorimetry and ion chromatography.

\begin{tabular}{|c|c|c|c|c|}
\hline & & Initial conditions (mM) & Mat tank (mM) & Control tank (mM) \\
\hline \multirow[t]{3}{*}{ Water conditions } & $T\left({ }^{\circ} \mathrm{C}\right)$ & 20.8 & $21.8 \pm 2.3$ & $21.7 \pm 1.9$ \\
\hline & $\mathrm{pH}$ & 8.4 & $8.5 \pm 0.6$ & $8.2 \pm 0.4$ \\
\hline & Conductivity $\left(\mathrm{mS} \cdot \mathrm{cm}^{-1}\right)$ & 49.4 & $54.9 \pm 1.7$ & $52.3 \pm 2.4$ \\
\hline Technique & Element & & & \\
\hline \multirow[t]{7}{*}{ ICP-AES } & $\mathrm{B}$ & - & 1.68 & 1.77 \\
\hline & $\mathrm{Ca}$ & 12.22 & 12.18 & 12.41 \\
\hline & $\mathrm{K}$ & 8.87 & 9.02 & 7.85 \\
\hline & $\mathrm{Mg}$ & 570.43 & 546.35 & 466.57 \\
\hline & $\mathrm{Na}$ & 563.68 & 693.98 & 576.46 \\
\hline & Si & - & 0.12 & 0.18 \\
\hline & $\mathrm{Sr}$ & - & 0.14 & 0.20 \\
\hline Colorimetric analysis & $\mathrm{H}_{4} \mathrm{SiO}_{4}$ & - & 0.14 & 0.15 \\
\hline \multirow[t]{3}{*}{ Ion chromatography } & $\mathrm{F}^{-}$ & - & 0.55 & 0.00 \\
\hline & $\mathrm{Cl}^{-}$ & 610.36 & 831.58 & 663.52 \\
\hline & $\mathrm{SO}_{4}^{2-}$ & 821.92 & 1031.54 & 847.38 \\
\hline
\end{tabular}

Measurements of dissolved silica, anions, and cations, the uncertainty of the measurements was better than $5 \%$.

Differential evaporation may also explain differences observed in $\mathrm{Na}$ or $\mathrm{Cl}$ for example between the control and the experiments. $\mathrm{Mg}$ (between 466 and $546 \mathrm{mM}$ ) and $\mathrm{Na}(576$ and $694 \mathrm{mM}$ ) were also major elements in water. $\mathrm{Ca}(>12 \mathrm{mM})$ and $\mathrm{K}$ (between 7.8 and $9 \mathrm{mM}$ ) were present at lower, yet relatively high concentrations. Several elements were also present at lower concentrations (below $1 \mathrm{mM}$ ). Concentrations of Si provided by ICP-AES $(0.12 \mathrm{mM})$ and colorimetric analyses $(0.14 \mathrm{mM})$ were consistent (Table 1). All these elements, in particular Mg, $\mathrm{Ca}$ and $\mathrm{Si}$ likely originated from the interactions between the solution and the sediments underlying the microbial mats. Based on these results and water $\mathrm{pH}$ (8.5) and temperature $\left(20^{\circ} \mathrm{C}\right)$, the ionic activities of several components were calculated. Saturation indexes (SI) of the solutions with several Mg-silicate phases, defined as the decadic logarithms of the ratio of the ion activity product over the solubility product constant (Ks), were calculated. Solubilities (expressed as Log Ks), estimated at $25^{\circ} \mathrm{C}$, of kerolite, sepiolite stevensite and talc were 25.79, 15.76 (Stoessell, 1988), 25.45 (Chahi et al., 1997), and 23.02 (Jones, 1986), respectively. Solutions in the microbial mat and the control tanks were significantly oversaturated with these different Mg-silicate phases, with SI-values of 5.54 for kerolite, 3.52 for sepiolite, 5.71 for stevensite, and 8.31 for talc in the microbial mat tank (see Supplementary Tables S1-S4).

\section{Electron Microscopy Analyses of the Carcasses}

Controls, as was described in previous experiments (Iniesto et al., 2013 b) decayed dramatically after a few months. At this time, the collection of the few residues of degraded fish over the sediment was impossible. Soft tissue was completely decayed and bones were disarticulated and broken at day 90 (Figure 1D). Long-term observations (more than a year) when we observed the first precipitates in the experiments could therefore not be performed on controls.

In contrast, after 4 years of incubation in microbial mats, carcasses inside the mats were exceptionally preserved at the macroscopic scale, as shown notably by the near intact state of the swim bladder (Figure 1E-a) and the vertebral column (Figure 1E-b). The precise delimitation of the interface between the fish and the biofilm was sometimes difficult to determine by SEM in secondary or backscattered electron modes (Figure 5A) because of the limited contrast difference between the biofilm and the external tissues of the fish such as muscles. For this reason, the position of the fish was determined by the detection of bones or fins, easily identified by their high chemical contrast (arrow in Figure 5A) due to the presence of $\mathrm{Ca}$ and $\mathrm{P}$. Although the transition between the mat and the fish was unclear, several inner soft-tissues appeared in the SEM as light gray areas (Figure S1). SEM observations of these lighter zones showed the presence of a widespread mineral phase rich in $\mathrm{Mg}$ and $\mathrm{Si}$ (circle in Figures 5A,B). This mineral phase was not detected in samples collected after a shorter incubation time as described in Iniesto et al. (2013b). In addition, bacillary cells were observed by SEM within the preserved tissues of the fish (arrow, Figure 5C).

Further observations and characterization of this $\mathrm{Mg}$ - and Si-rich phase was achieved based on STEM analyses of the FIB foils extracted from the inner tissues of a fish incubated within microbial mats for 4 years (Figure 6; Figure S1 shows the SEM zones chosen for FIB). Microbial cells embedded in the $\mathrm{Mg}$ Si phase were observed on the FIB foil (arrow, Figure 7). The transversal section of one of these cells appeared as a round shape filled with epoxy, and clearly delimited by an envelope measuring 50-100 $\mathrm{nm}$, also rich in $\mathrm{Mg}$ and Si. The surrounding matrix contained nanometer-sized $\mathrm{Mg}$-silicate grains with a 

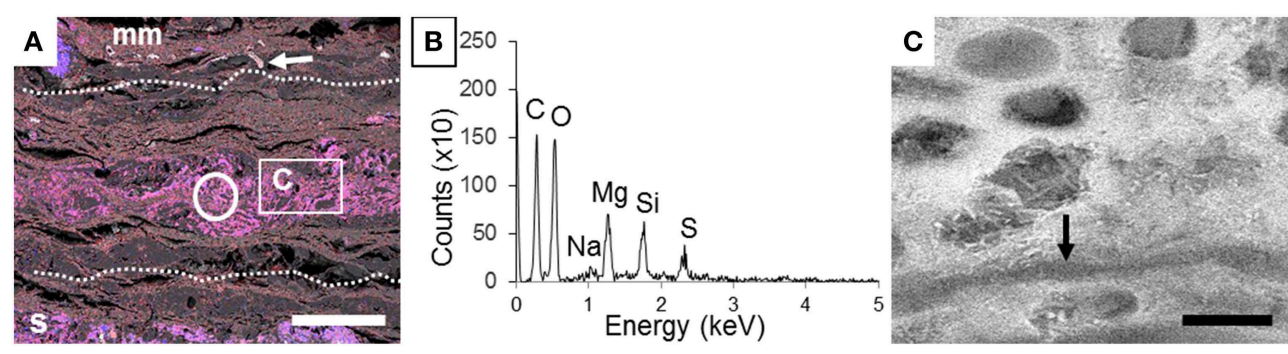

FIGURE 5 | Detection of a Mg silicate phase in the inner tissues of the fish after 4 years of incubation within a microbial mat. (A) Composite SEM-EDXS map of the section of the carcass incubated with a microbial mat. Si appears in blue and Mg in red. Dashed lines show the approximate limits of the fish. The circle marks the inner zone of the fish tissues analyzed by EDX in (B). Arrow points a fishbone. The box shows the zone highlighted in (C). (B) EDXS spectrum of the area outlined by a circle in (A). (C) SEM image of the inner mineralized tissue. Arrow highlights microbial filament. Scale bar represents $500 \mu \mathrm{m}$ in (A) and $2 \mu \mathrm{m}$ in (C).
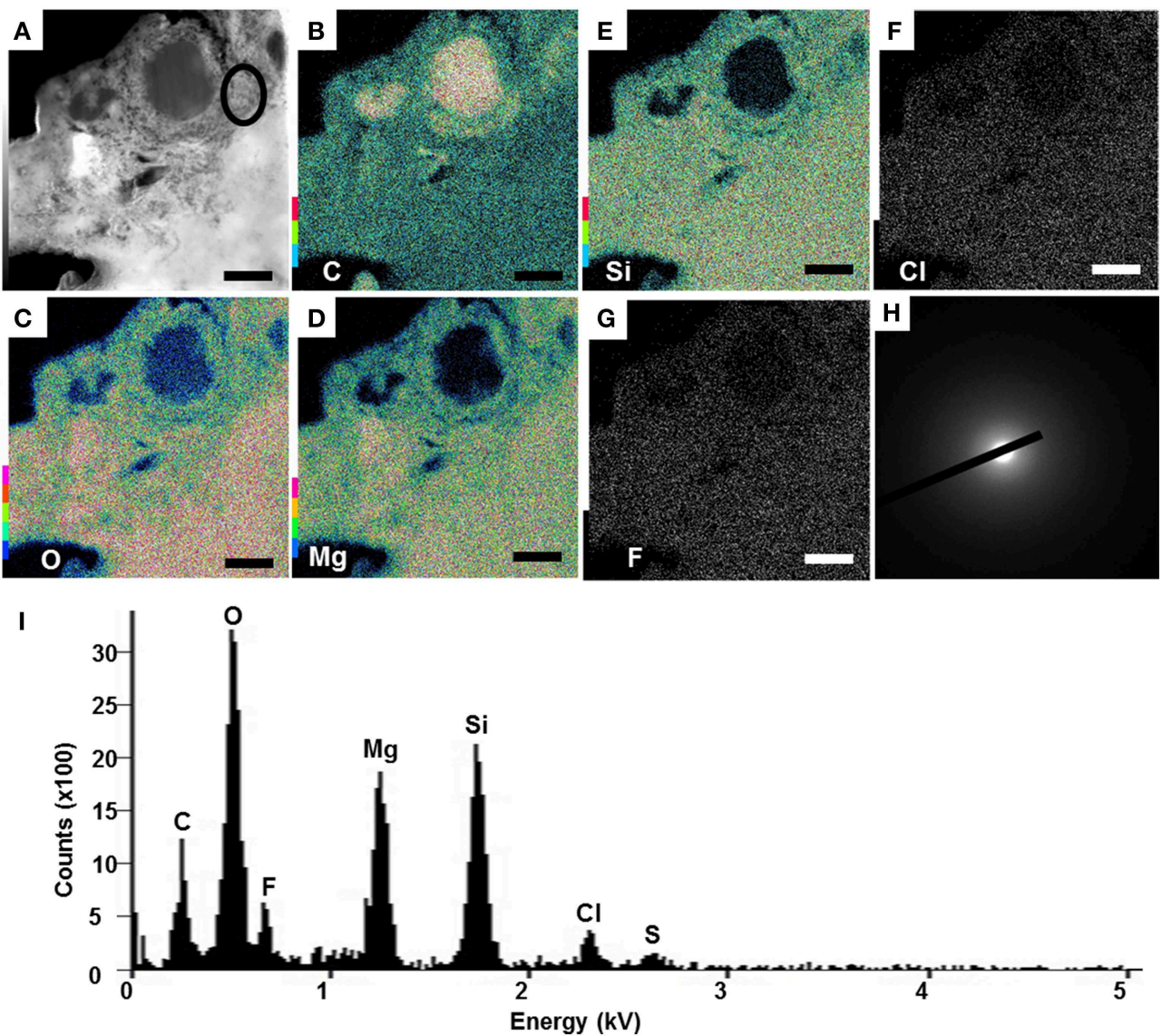

FIGURE 6 | TEM-EDXS maps of the inner fish tissue after 4 years. (A) TEM image of the analyzed area. (B-G) Carbon, oxygen, magnesium, silicon, chlorine, and fluor maps. (H) SAED pattern obtained on the Mg-silicate phase. The presence of diffuse rings only indicates the poor crystallinity of the phase. (I) EDXS spectrum of the area outlined by a circle in (A). All scale bars represent $1 \mu \mathrm{m}$.

homogeneous bright contrast. A $\mathrm{Mg} / \mathrm{Si}$ ratio of $\sim 0.77$ was assessed by EDXS analyses for this phase (Figures 6A-G and Table 2), which was poorly crystalline as suggested by SAED patterns (Figure $\mathbf{6 H}$ ). Minor amounts of $\mathrm{Cl}$ and $\mathrm{F}$ which may have precipitated during the sample drying process were also detected. $\mathrm{Cl}$ may alternatively be related to the epoxy resin (Figures 6F-G,I).
The Si- and Mg-rich phase was also present in fish carcasses incubated for 5 years. This phase formed a whole mineralized layer in the upper zone of the microbial mat (arrow, Figure 8A). Interestingly, the mineral phase appeared also close to the surface of the body and bones, especially over the dorsal fin: the hemitrichum that composes each thorn of the dorsal fin showed a $\mathrm{Mg}$-silicate coating (arrow, Figure 8B), and several bones 

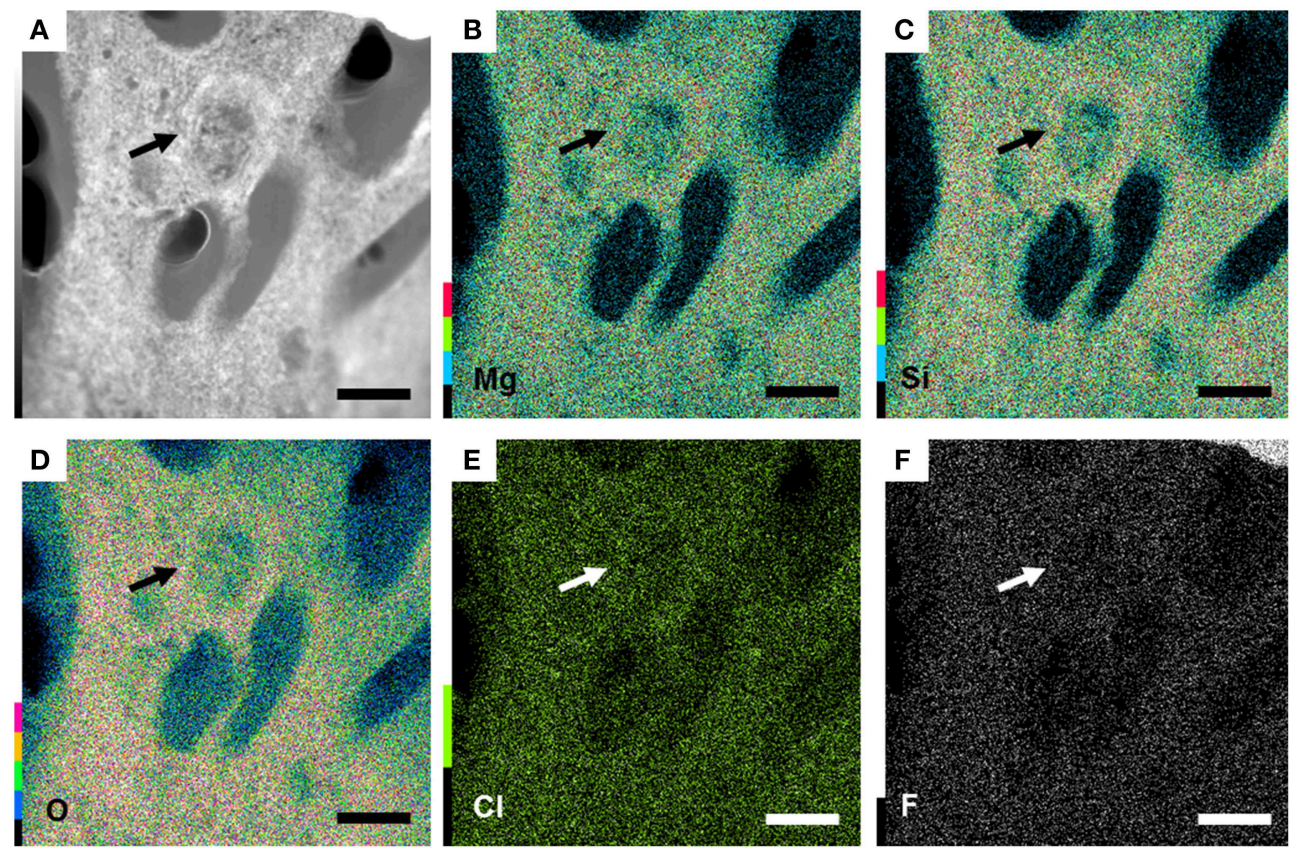

FIGURE 7 | Bacteria present in the preserved 4 years fish tissue, embedded in a Mg-rich silicate matrix. (A) TEM image of the section of a bacteria (arrow) (B-F) magnesium, silicon, oxygen, chlorine and fluor maps highlighting the enrichment in Si and Mg of the matrix. All scale bars represent $1 \mu \mathrm{m}$.

TABLE 2 | Elemental composition of the Mg-silicate phase as measured by TEM-EDXS on a FIB foil extracted from the inner tissue of a fish covered by microbial mat after 4 years.

\begin{tabular}{lccc}
\hline Element & Peak position (keV) & Atom $\%$ & Error\% \\
\hline F K & 0.677 & 5.14 & 0.29 \\
Na K & 1.041 & 1.58 & 1.38 \\
Mg K & 1.253 & 38.63 & 0.05 \\
Si K & 1.739 & 49.75 & 0.05 \\
S K & 2.307 & 1.42 & 1.09 \\
Cl K & 2.621 & 3.48 & 0.45 \\
\hline Total & & 100 & \\
\hline
\end{tabular}

Notice that the ratio $\mathrm{Mg} / \mathrm{Si}$ is close to $3 / 4(0.77)$.

seemed to be partially replaced by this phase (Figures $\mathbf{8 C}-\mathbf{F}$ ). In addition, the upper face of the head showed sometimes a similar replacement (Figures 9A,B). Close examination of the upper face of the head of the fish suggested that the replacement of the bone by Mg-silicate was gradual (Figure 9C), from a zone where calcium and phosphorous (principal constituent of bones) were predominant (Figure 9D) to an external zone, rich in Si and $\mathrm{Mg}$ (Figures 9E,F).

\section{Discussion}

Iniesto et al. (2013b) have demonstrated that microbial mats can favor the preservation of fossils. After the placement of a carcass at the top of the microbial community, the whole system experienced modifications that led to the quick coverage of the body by microorganisms. The microbial coverage generated a protective environment that delayed decay and promoted pseudomorphism allowing the exceptional preservation of carcasses in microbial mats (Guerrero et al., in press). In addition, the surfaces of bodies were copied as impressions in the inner face of the sarcophagi (Iniesto et al., 2013a).

The present work focuses on the possible additional role played by mineral precipitation in this preservation process. Our initial hypothesis was that increased preservation of fish tissues within the microbial mats may have resulted from enhanced mineral precipitation by microorganisms, forming some kind of mineral crust around the fish and therefore protecting them from further degradation. No such crust was observed here around carcasses but, in contrast, we observed a gradual transition from the microbial mats to the fish tissues at the micrometer scale. However, we detected the formation of an authigenic poorly-crystalline $\mathrm{Mg}$-silicate phase in relation with the decay of carcasses in the presence of a microbial mat in a long-term (few years) experiment.

A similar poorly crystalline and authigenic Mg-rich silicate phase has been observed previously in microbialites and lithifying mats (e.g., Kempe et al., 1991; Arp et al., 2003; Benzerara et al., 2010). In addition, the occurrence of similar silicates has been reported repeatedly in other diverse environments such as hot springs (Jones and Peng, 2014) or marine sediments (Badaut and Risacher, 1983). Stevensite, sepiolite, or kerolite (an hydrated talc-like phase) have been proposed as possible authigenic candidate phases forming under these conditions (e.g., Tosca and Masterson, 2014). Tosca and 

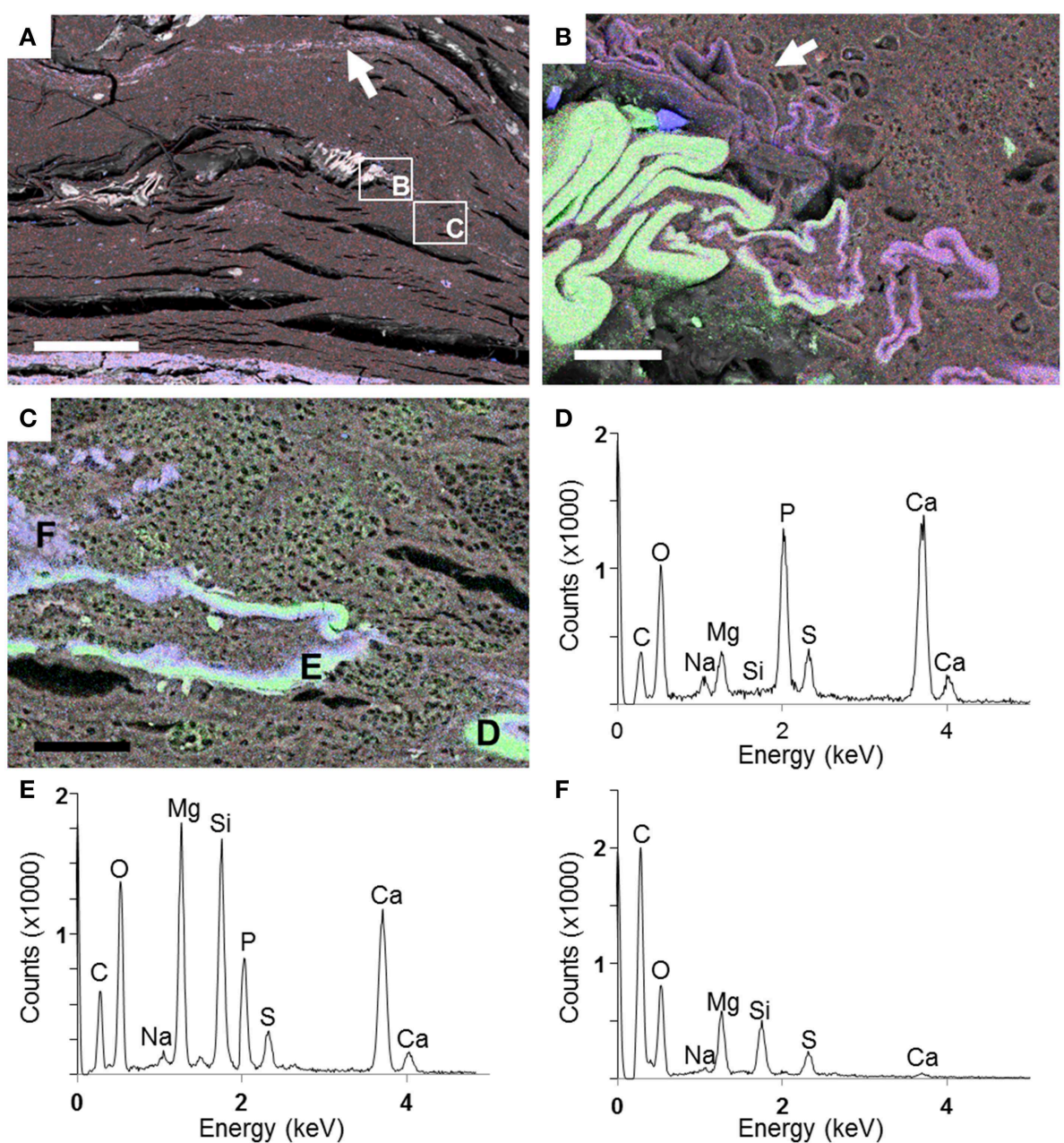

FIGURE 8 | SEM analyses of a fish after 5 years of incubation within a microbial mat. (A) General view of the section with a Si-Mg enriched layer in the top of the mat (arrow). Rectangles show zones of the preserved fish magnified in (B) and (C). (B) EDXS maps of Ca (green), Si (blue), and Mg (red) in the region of the dorsal fin (in green). A precipitated layer of Mg-silicate is highlighted by the arrow. (C) End of the dorsal fin where replacement of the bone (made by $\mathrm{Ca}-$ green-and $\mathrm{P}$ ) by the $\mathbf{M g}$-silicate phase (purple) is observed. (D-F) EDXS spectra corresponding to the spots labeled in (C). Scale bars represent $500 \mu \mathrm{m}$ in (A) and $30 \mu \mathrm{m}$ in (B,C).

Masterson (2014) showed that these phases can be distinguished based on FTIR spectroscopy and/or thermogravimetric analyses (TGA). However, these bulk techniques were not applicable in our study, where we needed to discriminate micrometer-scale phases lying within the fish carcasses from abundant phases within the sediments. Yet, the $\sim 3 / 4$ ratio for $\mathrm{Mg} / \mathrm{Si}$ provided by EDXS analyses pointed to kerolite and/or stevensite as the most likely Mg-silicate phases forming within fish. Interestingly, it has been noted by former studies that these phases can delicately fossilize microbial structures after cell death (SouzaEgipsy et al., 2005). Consistently with some of the previous studies, our data showed the embedment of microbial cells in this kerolite-like phase, supporting the hypothesis of its relatively good fossilization potential. Not only the inner tissue seems to be templated finely by this kerolite-like phase, but a gradual replacement by $\mathrm{Mg}$-silicates of the hydroxyapatite forming the bones of the fish was also observed. It is important to notice that the kerolite-like phase was only described in longterm experiments. Control fish without microbial mats decayed dramatically after only 2 months (Iniesto et al., 2013b) and this phase was not observed in any of them.

The mechanisms leading to the precipitation of this phase can be discussed. $\mathrm{Mg}$ and $\mathrm{Si}$ were provided by the solution which dissolved the $\mathrm{Mg}$ and Si-rich phases contained within the sediments. Quartz was the only Si-containing phase detected by DRX but is an improbable source of Si considering its low solubility. Poorly crystalline Mg-silicate phases, observed by SEM-EDX but not detected by DRX, may provide an alternative source of Si (Figure 2E). In that case, this kind of phase may dissolve in the sediments but reprecipitate in the fish due to a local microenvironment favorable to precipitation possibly in connection with the activity of microorganisms (see below). Another possibility is that the frustules of dead diatoms provide a source of $\mathrm{Si}$ for $\mathrm{Mg}$-silicate precipitation. It will be important 

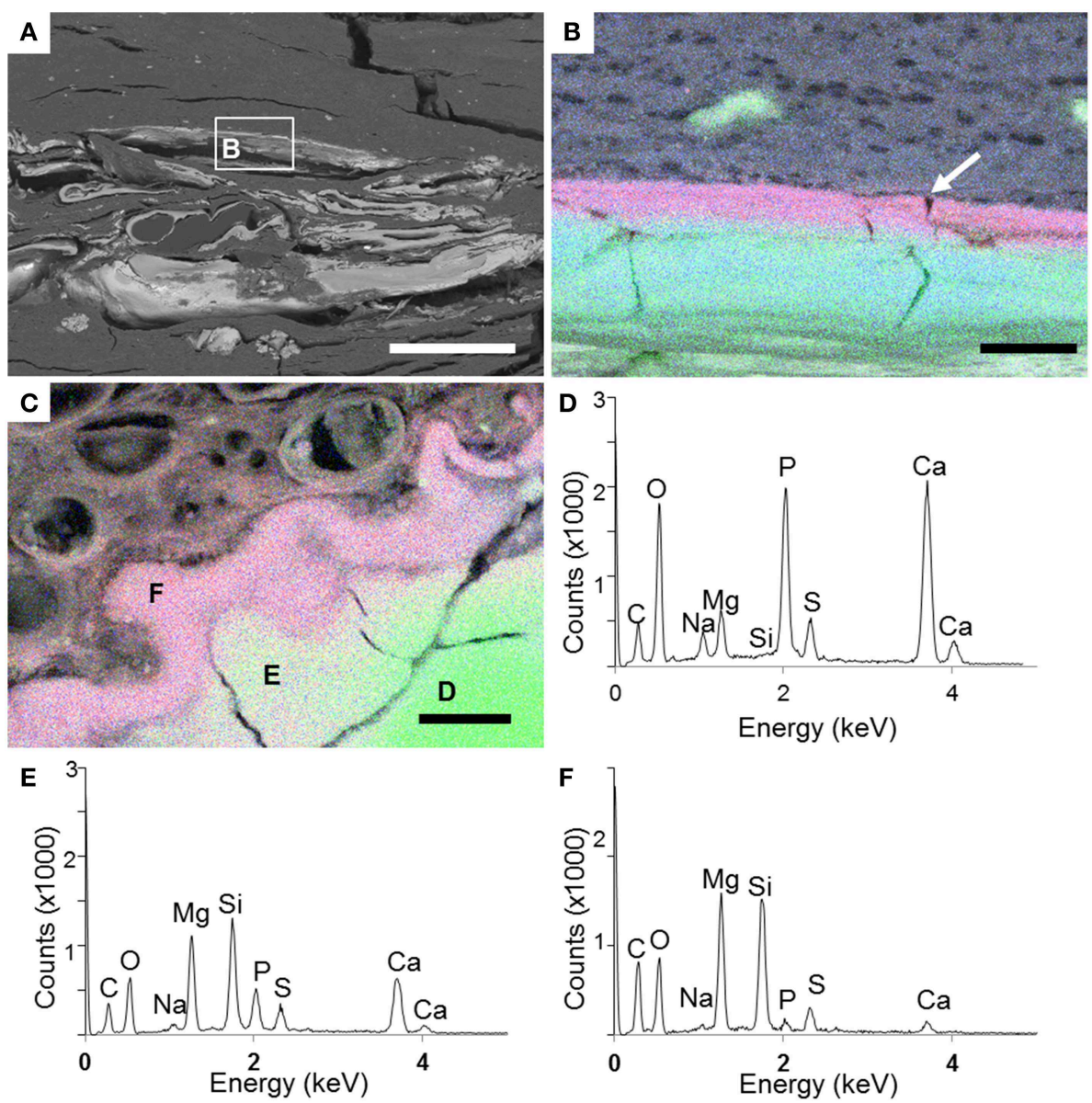

FIGURE 9 | SEM analyses of the head of a fish carcass after $\mathbf{5}$ years of incubation in a microbial mat. (A) General view of the head. (B) EDXS maps showing the localization of $\mathrm{Ca}$ (green), Si (blue), and Mg (red) around the head bone (green) as outlined in (A). The Mg-silicate phase (purple) delineates continuously the external side of the skull bone in the upper face (arrow). (C) Area of the skull where the bone is replaced by the Mg-silicate phase. (D-F) EDXS spectra corresponding to the spots shown in (C). Scale bars represent $400 \mu \mathrm{m}$ in $\mathbf{( A )}$ and $10 \mu \mathrm{m}$ in $\mathbf{( B , C ) .}$

in future studies to better quantify the budgets of these different Si reservoirs. Mineralogical and sedimentological observations have documented similar early diagenetic hydrated Mg-silicate mineral phases in carbonate-dominated deposits (Friedman, 1965; Noack et al., 1989; Calvo et al., 1999). Such phases can precipitate at ambient temperature in supersaturated solutions (e.g., Gac et al., 1977; Kent and Kastner, 1985; Tosca et al., 2011) following the reaction (written for kerolite):

$3 \mathrm{Mg}^{2+}+4 \mathrm{SiO}_{2}(\mathrm{aq})+5 \mathrm{H}_{2} \mathrm{O} \rightarrow \mathrm{Mg}_{3} \mathrm{Si}_{4} \mathrm{O}_{10}(\mathrm{OH})_{2} \cdot \mathrm{H}_{2} \mathrm{O}+6 \mathrm{H}^{+}$

As shown by reaction (1), precipitation of kerolite is favored by increased activities of $\mathrm{Mg}^{2+}, \mathrm{SiO}_{2}$, and a higher $\mathrm{pH}$. Moreover, it is known that kinetic barriers can limit precipitation at low temperatures and that precipitation of such a mineral phase may therefore only occur when the solution is significantly oversaturated. According to chemical analyses, solutions were significantly oversaturated ( $>5$ for kerolite or stevensite) in the present experiments and therefore these phases may have precipited everywhere in the tanks. The preferential precipitation of Mg-silicate at discrete sites within the fish may have resulted from a local $\mathrm{pH}$ increase during the transformation of carcasses within microbial mats. During the coverage of bodies by the microbial mat, a short-standing phase with an increase of acidity in the system was actually described, although a stable basic $\mathrm{pH}$ (above 8.5) was recovered afterwards, affecting especially the top-face of the fish (Iniesto et al., 2015). This increase with an unequal spatial distribution depends dramatically on the presence of these microbial communities. This relatively high $\mathrm{pH}$ can be explained by the photosynthetic activity in the upper oxic layers (Jonkers et al., 2003), as well as, locally, the dissolution of hydroxyapatite of bones. The preferential localization of $\mathrm{Mg}$ silicate precipitation around bones and fines in the upper face of carcasses may therefore result from these latter processes. Moreover, the presence of preferential nucleation surfaces may counteract kinetic barriers and favor precipitation (e.g., De Yoreo and Velikov, 2003). It may be hypothesized that microbial cell surfaces and/or extracellular polymers, decaying tissues and/or bone surfaces may provide such preferential nucleation sites for Mg-silicates, similarly to what was described by Ueshima 
and Tazaki (2001) for Fe-rich silicate precipitation. Depending on the stability of this phase, tissues and bones would be preserved as a talc-like fossil. Tosca and Masterson (2014) mentioned that this kind of poorly crystalline phases should be replaced by more crystalline phases over geological times, through dehydration and concomitant crystallographic ordering. This may decrease slightly the quality of structural preservation at the submicrometer-scale. However, it should be noted that some ancient fossils of soft tissues of metazoans have been preserved by clays, including within metamorphic rocks of relatively high grade (Zhang and Briggs, 2007; Galvez et al., 2012; Wacey et al., 2014), supporting the plausibility of fossil preservation by such silicates.

In conclusion, the present experiments show the first steps of early mineralization of fish carcasses covered by microbial mats. They confirm the influence of microbial mats on the fossilization of metazoans. More than 4 years after the beginning of the decay, inner tissues or bones were gradually replaced by a fine and poorly-crystalline Mg-silicate phase. Fluids permeating the system were oversaturated with kerolite and stevensite, as a likely result of partial dissolution of the underlying sediments rich in quartz, gypsum, kieserite, aragonite other minor $\mathrm{Mg}$ and Si-containing phases and/or the frustules of dead diatoms composed of amorphous silica. Moreover, local processes, possibly linked with biological activity (rising $\mathrm{pH}$ and/or offering preferential nucleation sites) may have played as well in favoring the precipitation of authigenic Mg-silicates. While exceptional

\section{References}

Arp, G., Reimer, A., and Reitner, J. (2003). Microbialite formation in seawater of increased alkalinity, Satonda Crater Lake, Indonesia. J. Sediment. Res. 73, 105-127. doi: 10.1306/071002730105

Badaut, D., and Risacher, F. (1983). Authigenic smectite on diatom frustules in bolivian saline lakes. Geochim. Cosmochim. Acta 47, 363-375. doi: 10.1016/0016-7037(83)90259-4

Benzerara, K., Meibom, A., Gautier, Q., Ka mierczak, J., Stolarski, J., Menguy, N., et al. (2010). Nanotextures of aragonite in stromatolites from the quasimarine Satonda Crater Lake, Indonesia. Geol. Soc. Lond. 336, 211-224. doi: 10.1144/SP336.10

Benzerara, K., Menguy, N., Guyot, F., Vanni, C., and Gillet, P. (2005a). High resolution study of silicate-carbonate-micro-organism interface prepared by focused ion beam (FIB). Geochim. Cosmochim. Acta 69, 1413-1422. doi: 10.1016/j.gca.2004.09.008

Benzerara, K., Menguy, N., Guyot, F., Vanni, C., and Gillet, P. (2005b). TEM study of a silicate-carbonate-microbe interface prepared by focused ion beam milling. Geochim. Cosmochim. Acta 69, 1413-1422. doi: 10.1016/j.gca.2004.09.008

Berga, A., Cabrera, M., and Legaz, A. (1994). "Medidas correctoras en el funcionamiento hídrico de la Laguna Salada de Chiprana," in Actas de las "Jornadas Sobre el Futuro de las Saladas de los Monegros y el Bajo Aragón," (Zaragoza: Grupo Cultural Caspolino), 113-122.

Bernard, S., Benzerara, K., Beyssac, O., and Brown, G. E. (2010). Multiscale characterization of pyritized plant tissues in blueschist facies metamorphic rocks. Geochim. Cosmochim. Acta 74, 5054-5068. doi: 10.1016/j.gca.2010.06.011

Bernard, S., Beyssac, O., and Benzerara, K. (2008). Raman mapping using advanced line-scanning systems: geological applications. Appl. Spectrosc. 62, 1180-1188. doi: $10.1366 / 000370208786401581$

Beyssac, O., Goffé, B., Petitet, J.-P., Froigneux, E., Moreau, M., and Rouzaud, J.-N. (2003). On the characterization of disordered and heterogeneous carbonaceous preservation can be the result of different abiotic processes such as obrution and/or stagnation (Seilacher et al., 1985), the present results evidence that precipitation of authigenic silicates may favor this preservation at least in some environments, here characterized by alkaline and Mg-rich fluids. The experimental fossilization of a vertebrate by a talc-like mineral is here revealed for the first time and further work on the long-term fate of such fossils replaced by this type of mineral phase will be needed.

\section{Acknowledgments}

This work, which is part of the research projects CGL201342643P and the research grant supporting MI were funded by the Spanish Ministry of Economy and Competitiveness. The SEM facility at IMPMC was supported by Region Ile de France grant SESAME 2006 I-07-593/R, INSU-CNRS, INP-CNRS, and University Pierre et Marie Curie, Paris. SEM analyses performed for this study were supported by a grant from the Foundation Simone et Cino Del Duca (PI: KB). We are also especially grateful to Olivier Beyssac for the help provided for RAMAN analysis.

\section{Supplementary Material}

The Supplementary Material for this article can be found online at: http://journal.frontiersin.org/article/10.3389/feart. 2015.00051 materials by Raman spectroscopy. Spectrochim. Acta A Mol. Biomol. Spectrosc. 59, 2267-2276. doi: 10.1016/S1386-1425(03)00070-2

Beyssac, O., and Lazzeri, M. (2012). "Application of Raman spectroscopy to the study of graphitic carbons in the Earth Sciences," in Applications of Raman Spectroscopy to Earth Sciences and Cultural Heritage. EMU Notes in Mineralogy Vol. 12, eds. J. Dubessy, M. C. Caumon, and F. Rull (Twickenham: European Mineralogical Union and the Mineralogical Society of Great Britain and Ireland), 415-454.

Briggs, D. E. G., Moore, R., a, Shultz, J. W., and Schweigert, G. (2005). Mineralization of soft-part anatomy and invading microbes in the horseshoe crab Mesolimulus from the Upper Jurassic Lagerstätte of Nusplingen, Germany. Proc. Biol. Sci. 272, 627-632. doi: 10.1098/rspb. 2004.3006

Briggs, D. E. G., Wilby, P. R., Pérez-Moreno, B. P., Sanz, J. L., and FregenalMartínez, M. A. (1997). The mineralization of dinosaur soft tissue in the lower Cretaceous of Las Hoyas, Spain. J. Geol. Soc. Lond. 154, 587-588. doi: 10.1144/gsjgs.154.4.0587

Calvo, J. P., Blanc-Valleron, M. M., Rodríguez-Arandía, J. P., Rouchy, J. M., and Sanz, M. E. (1999). Authigenic clay minerals in continental evaporitic environments. Spec. Publ. IAS 27, 129-151. doi: 10.1002/978144430 4190.ch5

Chahi, A., Fritz, B., Duplay, J., Weber, F. J., and Lucas, J. (1997). Textural transition and genetic relationship between precursor stevensite and sepiolite in Lacustrine sediments (Jbel Rhassoul, Morocco). Clays Clay Miner. 45, 378-389. doi: 10.1346/CCMN.1997.0450308

Cohen, Y. (1989). "Preface," in Microbial Mats: Physiological Ecology and Benthic Microbial Communities, eds Y. Cohen and E. Rosenberg (Washington, DC: American Society for Microbiology), XV-XVII.

Couradeau, E., Benzerara, K., Gérard, E., Estève, I., Moreira, D., Tavera, R., et al. (2013). Cyanobacterial calcification in modern microbialites at the submicrometer scale. Biogeosciences 10, 5255-5266. doi: 10.5194/bg-10-52 $55-2013$ 
Darroch, S., Laflamme, M., Schiffbauer, J. D., and Briggs, D. E. G. (2012). Experimental formation of a microbial death mask. Palaios 27, 293-303. doi: 10.2110/palo.2011.p11-059r

De Yoreo, J. J., and Velikov, P. G. (2003). Principles of crystal nucleation and growth. Rev. Mineral. Geochem. 54, 57-93. doi: 10.2113/0540057

Dupraz, C., Reid, R. P., Braissant, O., Decho, A. W., Norman, R. S., and Visscher, P. T. (2009). Processes of carbonate precipitation in modern microbial mats. Earth Sci. Rev. 96, 141-162. doi: 10.1016/j.earscirev.2008.10.005

Dupraz, C., and Visscher, P. T. (2005). Microbial lithification in marine stromatolites and hypersaline mats. Trends Microbiol. 13, 429-438. doi: 10.1016/j.tim.2005.07.008

Friedman, G. M. (1965). Occurrence of talc as a clay mineral in sedimentary rocks. Nature 207, 283-284. doi: 10.1038/207283a0

Friend, P., Hirst, J., and Nichols, G. J. (1986). Sandstone body structure and river process in the Ebro basin Aragón, Spain. Cuad. Geol. Ibérica 10, 9-30.

Gac, J. Y., Droubi, A., Fritz, B., and Tardy, Y. (1977). Geochemical behaviour of silica and magnesium during the evaporation of waters in Chad. Chem. Geol. 19, 215-228. doi: 10.1016/0009-2541(77)90016-X

Galvez, M. E., Beyssac, O., Benzerara, K., Bernard, S., Menguy, N., Cox, S. C., et al. (2012). Morphological preservation of carbonaceous plant fossils in blueschist metamorphic rocks from New Zealand. Geobiology 10, 118-129. doi: 10.1111/j.1472-4669.2011.00316.x

Gehling, J. G. (1999). Microbial mats in terminal proterozoic siliciclastics: ediacaran death masks. Palaios 14, 40. doi: 10.2307/3515360

Gérard, E., Ménez, B., Couradeau, E., Moreira, D., Benzerara, K., Tavera, R., et al. (2013). Specific carbonate-microbe interactions in the modern microbialites of Lake Alchichica (Mexico). ISME J. 7, 1997-2009. doi: 10.1038/ismej.2013.81

Gerdes, G., Claes, M., Dunajtschik-Piewak, K., Riege, H., Krumbein, W. E., and Reineck, H.-E. (1993). Contribution of microbial mats to sedimentary surface structures. Facies 29, 61-74. doi: 10.1007/BF02536918

Guerrero, M. C., Balsa, J., Pascual, M., Martínez, B., and Montes, C. (1991). Caracterización limnológica de la laguna salada de Chiprana (Zaragoza, Espana) y sus comunidades de bacterias fototroficas. Limnetica 7, 83-96.

Guerrero, M. C., López-Archilla, A. I., and Iniesto, M. (in press). "III.4.Microbial mats and preservation," in Las Hoyas: A Cretaceous Wetland: A Multidisciplinary Synthesis after 25 years of Research on an Exceptional Fossil Lagerstätte from Spain, eds F. J. Poyato-Ariza and Á. D. Buscalioni (München: Verlag Dr. Friedrich Pfeil).

Gupta, N. S., Cambra-moo, O., Briggs, D. E. G., Love, G. D., Fregenal-Martínez, M. A., and Summons, R. E. (2008). Molecular taphonomy of macrofossils from the Cretaceous Las Hoyas Formation, Spain. Cretac. Res. 29, 1-8. doi: 10.1016/j.cretres.2006.12.009

Hagadorn, J. W., and Bottjer, D. J. (1997). Wrinkle structures: microbially mediated sedimentary structures common in subtidal siliciclastic settings at the proterozoic-phanerozoic transition. Geology 25, 1047-1050.

Iniesto, M., Benzerara, K., Guerrero, M. C., Buscalioni, Á. D., and López-Archilla, A. I. (2013a). "Formación de moldes en tapetes microbianos y su importancia en la Tafonomía," in Abstracts del XXIV Congreso de Microbiología, (Barcelona: Sociedad Española de Microbiología), 234

Iniesto, M., Laguna, C., Chicote, Á., Peñín, I., Guerrero, M. C., Florín, M., et al. (2010). "Estudio de los microperfiles de oxígeno y potencial REDOX en tapetres microbianos aplicados a ensayos de actuotafonomía," in Abstracts de la VII Reunión del Medio Acuático, eds T. P. Nieto, L. A. Rodríguez, M. J. Pérez, and R. Farto (Vigo: Sociedad Española de Microbiología), 65-66.

Iniesto, M., Laguna, C., Florín, M., Guerrero, M. C., Chicote, Á., Buscalioni, Á. D., et al. (2015). "Preservation in mats described at a micrometric scale with microsensors," in Avances en Microbiología, ed E. González-Fandos (Logroño: Servicio de Publicaciones de la Universidad de La Rioja), 323-324.

Iniesto, M., López-Archilla, A. I., Fregenal-Martínez, M. A., Buscalioni, Á. D., and Guerrero, M. C. (2013b). Involvement of microbial mats in delayed decay: an experimental essay on fish preservation. Palaios 28, 56-66. doi: 10.2110/palo.2011.p11-099r

Jones, B. F. (1986). "Clay mineral diagenesis in lacustrine sediments," in Studies in Diagenesis, Vol. 1578, ed F. A. Mumpton (Washington, DC: USGS Bulletin; U.S. Geological Survey), 291-300.

Jones, B., and Peng, X. (2014). Signatures of biologically influenced CaCO3 and $\mathrm{Mg}$-Fe silicate precipitation in hot springs: case study from the Ruidian geothermal area, western Yunnan Province, China. Sedimentology 61, 56-89. doi: $10.1111 /$ sed.12043

Jonkers, H. M., Ludwig, R., De Wit, R., Pringault, O., Muyzer, G., Niemann, H., et al. (2003). Structural and functional analysis of a microbial mat ecosystem from a unique permanent hypersaline inland lake: "La Salada de Chiprana" (NE Spain). FEMS Microbiol. Ecol. 44, 175-189. doi: 10.1016/S0168-6496(02) 00464-6

Kaye, T. G., Gaugler, G., and Sawlowicz, Z. (2008). Dinosaurian soft tissues interpreted as bacterial biofilms. PLoS ONE 3:e2808. doi: 10.1371/journal.pone.0002808

Kempe, S., Kaźmierczak, J., Landmann, G., Konuk, T., Reimer, A., and Lipp, A. (1991). Largest known microbialites discovered in Lake Van, Turkey. Nature 349, 605-608. doi: 10.1038/349605a0

Kent, D. B., and Kastner, M. (1985). Mg2+ removal in the system Mg2+amorphous $\mathrm{SiO} 2$ by adsorption and $\mathrm{Mg}$-hydroxysilicate precipitation. Geochim. Cosmochim. Acta 49, 1123-1136. doi: 10.1016/0016-7037(85)90003-1

Laflamme, M., Schiffbauer, J. D., Narbonne, G. M., and Briggs, D. E. G. (2011). Microbial biofilms and the preservation of the Ediacara biota. Lethaia 44, 203-213. doi: 10.1111/j.1502-3931.2010.00235.x

Li, J., Benzerara, K., Bernard, S., and Beyssac, O. (2013). The link between biomineralization and fossilization of bacteria: insights from field and experimental studies. Chem. Geol. 359, 49-69. doi: 10.1016/j.chemgeo.2013.09.013

Liu, Y., Wang, A., and Freemen, J. J. (2009). "Raman, MIR, and NIR spectroscopic study of calcium sulfates: gypsum, bassanite, and anhydrite," in 40th Lunar and Planetary Science Conference. 2128. Available online at: http://adsabs.harvard. edu/abs/2009LPI....40.2128L (Accessed April 2, 2015).

Marty, D., Belvedere, M., Meyer, C. A., Mietto, P., Paratte, G., Lovis, C., et al. (2010). Comparative analysis of Late Jurassic sauropod trackways from the Jura Mountains (NW Switzerland) and the central High Atlas Mountains (Morocco): implications for sauropod ichnotaxonomy. Hist. Biol. 22, 109-133. doi: 10.1080/08912960903503345

Marty, D., Strasser, A., and Meyer, C. A. (2009). Formation and taphonomy of human footprints in microbial mats of present-day tidal-flat environments: implications for the study of fossil footprints. Ichnos 16, 127-142. doi: $10.1080 / 10420940802471027$

Narbonne, G. M. (2005). The ediacara biota: neoproterozoic origin of animals and their ecosystems. Annu. Rev. Earth Planet. Sci. 33, 421-442. doi 10.1146/annurev.earth.33.092203.122519

Noack, Y., Decarreau, A., Boudzoumou, F., and Trompette, R. (1989). Lowtemperature oolitic talc in upper proterozoic rocks, Congo. J. Sediment Res. 59, 717-723. doi: 10.1306/212F9057-2B24-11D7-8648000102C1865D

Noffke, N. (2009). The criteria for the biogeneicity of microbially induced sedimentary structures (MISS) in Archean and younger, sandy deposits. Earth Sci. Rev. 96, 173-180. doi: 10.1016/j.earscirev.2008.08.002

Noffke, N., Gerdes, G., Klenke, T., and Krumbein, W. E. (2001). Perspectives microbially induced sedimentary structures-a new category within the classification of primary sedimentary structures. J. Sediment. Res. 71, 649-656 doi: 10.1306/2DC4095D-0E47-11D7-8643000102C1865D

Seilacher, A., Reif, W.-E., Westphal, F., Riding, R., Clarkson, E. N. K., and Whittington, H. B. (1985). Sedimentological, ecological and temporal patterns of fossil lagerstatten [and Discussion]. Philos. Trans. R. Soc. B Biol. Sci. 311, 5-24. doi: 10.1098/rstb.1985.0134

Siegesmund, M. A., Johansen, J. R., Karsten, U., and Friedl, T. (2008). Coleofasciculus gen. nov. (Cyanobacteria): morphological and molecular criteria for revision of the genus Microcoleus gomont. J. Phycol. 44, 1572-1585. doi: 10.1111/j.1529-8817.2008.00604.x

Souza-Egipsy, V., Wierzchos, J., Ascaso, C., and Nealson, K. H. (2005). Mgsilica precipitation in fossilization mechanisms of sand tufa endolithic microbial community, Mono Lake (California). Chem. Geol. 217, 77-87. doi: 10.1016/j.chemgeo.2004.12.004

Stoessell, R. K. (1988). $25^{\circ} \mathrm{C}$ and 1 atm dissolution experiments of sepiolite and kerolite. Geochim. Cosmochim. Acta 52, 365-374. doi: 10.1016/00167037(88)90092-0

Tosca, N. J., Macdonald, F. A., Strauss, J. V., Johnston, D. T., and Knoll, A. H. (2011). Sedimentary talc in Neoproterozoic carbonate successions. Earth Planet. Sci. Lett. 306, 11-22. doi: 10.1016/j.epsl.2011.03.041 
Tosca, N. J., and Masterson, A. L. (2014). Chemical controls on incipient Mg-silicate crystallization at $25^{\circ} \mathrm{C}$ : implications for early and late diagenesis. Clay Miner. 49, 165-194. doi: 10.1180/claymin.2014. 049.2.03

Ueshima, M., and Tazaki, K. (2001). Possible role of microbial polysaccharides in nontronite formation. Clays Clay Miner. 49, 292-299. doi: 10.1346/CCMN.2001.0490403

Urmos, J., Sharma, S., and Mackenzie, F. (1991). Characterization of some biogenic carbonates with Raman spectroscopy. Am. Mineral. 76, 641-646.

Vasconcelos, C., Warthmann, R., McKenzie, J. A., Visscher, P. T., Bittermann, A. G., and van Lith, Y., (2006). Lithifying microbial mats in Lagoa Vermelha, Brazil: modern precambrian relics? Sediment. Geol. 185, 175-183. doi: 10.1016/j.sedgeo.2005.12.022

Visscher, P. T., Reid, R. P., Bebout, B. M., Hoeft, S. E., Macintyre, I. G., and Thompson, J. R., J. A. (1998). Formation of lithified micritic laminae in modern marine stromatolites (Bahamas): the role of sulfur cycling. Am. Mineral. 83, 1482-1493.

Wacey, D., Saunders, M., Roberts, M., Menon, S., Green, L., Kong, C., et al. (2014). Enhanced cellular preservation by clay minerals in 1 billion-year-old lakes. Sci. Rep. 4, 5841. doi: 10.1038/srep05841
White, S. N. (2009). Laser Raman spectroscopy as a technique for identification of seafloor hydrothermal and cold seep minerals. Chem. Geol. 259, 240-252. doi: 10.1016/j.chemgeo.2008.11.008

Wierzchos, J., Berlanga, M., Ascaso, C., and Guerrero, R. (1996). Micromorphological characterization and lithification of microbial mats from the Ebro Delta (Spain). Int. Microbiol. 9, 289-295.

Zhang, X., and Briggs, D. E. G. (2007). The nature and significance of the appendages of Opabinia from the Middle Cambrian Burgess Shale. Lethaia 40, 161-173. doi: 10.1111/j.1502-3931.2007.00013.x

Conflict of Interest Statement: The authors declare that the research was conducted in the absence of any commercial or financial relationships that could be construed as a potential conflict of interest.

Copyright (c) 2015 Iniesto, Zeyen, López-Archilla, Bernard, Buscalioni, Guerrero and Benzerara. This is an open-access article distributed under the terms of the Creative Commons Attribution License (CC BY). The use, distribution or reproduction in other forums is permitted, provided the original author(s) or licensor are credited and that the original publication in this journal is cited, in accordance with accepted academic practice. No use, distribution or reproduction is permitted which does not comply with these terms. 